\title{
Comparison of Proliferative Activity of Epithelial Cells between the Follicles of Impacted Teeth
}

\author{
Comparación de la Actividad Proliferativa de las Células \\ Epiteliales entre los Folículos de Dientes Impactados
}

\author{
Nurgül Kömerik*; Alper Tufan*** \& Nilgün Kapucuoglu****
}

KÖMERIK, N.; TUFAN, A. \& KAPUCUOGLU, N. Comparison of proliferative activity of epithelial cells between the follicles of impacted teeth. Int. J. Morphol., 32(4):1296-1302, 2014.

SUMMARY: The aim of this comparative observational study was to compare the proliferative activity of dental follicles surrounding impacted maxillary canines and mandibular third molars. Following extraction, forty follicles of the impacted mandibular third molars and 40 follicles of the impacted maxillary canines were removed. Epithelial cell proliferative activity of these samples was assessed using immunohistochemical labeling for Ki-67, minichromosome maintenance 2 (MCM-2) protein and epithelial growth factor receptor (EGFR). Intensity and extent of Ki-67, MCM-2 and EGFR expressions were evaluated by a scoring formula. The lining epithelium of the maxillary canine follicles had mean scores of $4.65 \pm 0.27$ for Ki-67, $1.25 \pm 0.33$ for MCM-2 and 7.30 \pm 0.23 for EGFR which were not significantly different than those expressed in the mandibular third molar follicles $(4.46 \pm 0.26$ for Ki-67, $1.39 \pm 0.33$ for MCM-2 and $7.21 \pm 0.20$ for EGFR). The expression of Ki-67 and MCM- 2 could not be detected in the epithelial remnants within the connective tissue in both groups. EGFR expression, detected in the epithelial remnants in both groups, was not significantly different (7.28 \pm 0.14 in the canine group as opposed to $7.21 \pm 0.16$ in the third molar group). Based on these findings, it can be deduced that impacted mandibular third molars and maxillary canines carry similar risk of pathology development.

KEY WORDS: Dental follicle; Ki-67; MCM-2; EGFR; Immunohistochemistry.

\section{INTRODUCTION}

Impacted teeth may present various problems which mandate their extraction. For instance, they may cause pericoronitis, caries or resorption of the adjacent second molar due to their spatial errant positioning. Dental follicles surrounding the crown of the impacted teeth may also be the source of pathology such as odontogenic cysts and tumors. When compared to the rest of impacted teeth, impacted mandibular third molars are much more commonly associated with such pathologies (Ochsenius et al., 2007). Higher rate of occurrence of pathology associated with mandibular third molars may simply be as a result of higher incidence of their impaction (Chu et al., 2003). Yet, it may also be due to the higher pathogenic potential of the dental follicles mandibular third molars have.

An increase in cell proliferative activity has been considered as an early indicator of irregular growth of the tissues (Liu \& Klein-Szanto, 2000). Expressions of immunological markers in oral dysplastic lesions were found to be higher than those in the healthy oral mucosa. Moreover, expressions of these markers were increased with the severity of epithelial dysplasia (Macluskey et al., 1999; Szelachowska et al., 2006). The immunological proliferation-related markers were also suggested as useful tools in predicting the different biological behavior of the odontogenic lesions. Expression of proliferation-related markers in odontogenic ameloblastomas and odontogenic keratocysts was higher than orthokeratinized odontogenic cysts and dentigerous cysts (Piattelli et al., 2002). Ki-67, minichromosome maintenance 2 (MCM-2) protein and epithelial growth factor receptor (EGFR) are the commonly employed immunological markers of which sensitivity to show cell proliferative activity was demonstrated (Macluskey et al.; Szelachowska et al.; Piattelli et al.).

Dental follicles, derived from odontogenic ectomesenchyme, are histologically characterized by fibrous connective tissue with variable amounts of lining epithelium

\footnotetext{
* Dept. of Oral and Maxillofacial Surgery, Suleyman Demirel University, Dental School, Isparta, Turkey.

** Resident, Dept. of Oral and Maxillofacial Surgery, Suleyman Demirel University, Dental School, Isparta, Turkey.

*** Dept. of Pathology, Suleyman Demirel University, Medical School, Isparta, Turkey.
} 
and epithelium remnants within the connective tissue. Odontogenic cysts or tumors could arise from these odontogenic epithelial components. Proliferative activity of epithelial cells in the dental follicles may reflect the pathogenic potential of the impacted teeth. The proliferative potential of dental follicles surrounding the crown of unerupted/impacted teeth has not yet been investigated in detail. Earlier studies focused on the follicles of impacted mandibular third molars (Szelachowska et al.; Piattelli et al.; Adelsperger et al., 2000; da Silva Baumgart et al., 2007; Oliveira et al., 2011, 2012; Özarslan et al., 2013) and their associated pathologies (Saraçoglu et al., 2005; Edamatsu et al., 2005; Cabbar et al., 2008; Güler et al., 2012). To the knowledge of the authors, there is no data on the proliferative capacity of follicles of impacted teeth other than mandibular third molars. Therefore, the aim of this study is to compare the proliferative activity (hence pathogenic potential) of dental follicles of the impacted maxillary canines to that of the impacted mandibular third molars using immunolabeling for Ki-67, MCM-2 and EGFR markers.

\section{MATERIAL AND METHOD}

The project protocol was reviewed and approved by the institutional Clinical Studies Ethics Committee, was in compliance with the Helsinki Declaration, and each subject in the project signed a detailed informed consent form.

The patients who referred to the clinics of Oral and Maxillofacial Surgery for the removal of fully impacted mandibular third molar or maxillary canine were screened for the eligibility to participate in the study. The inclusion criteria were 18 and above years of age, being healthy, nonsmoking, negative history of medication for the last two weeks, presence of clinically and radiographically asymptomatic fully impacted mandibular third molar or maxillary canine that have closed apex and have pericoronal radiolucency of $2.5 \mathrm{~mm}$ or less in the greatest dimension. Those who met the inclusion criteria were approached and were asked if they would like to take part in the study. A total of 80 patients, 40 having impacted maxillary canine (allocated as canine group) and 40 having impacted mandibular third molar (allocated as third molar group), were included in the study.

Following standard surgical procedures under local anesthesia, impacted teeth were extracted. Dental follicles were then curetted out from the extraction socket carefully and were placed immediately in $10 \%$ formalin for fixation.

The samples were embedded in paraffin wax and 5- $\mu \mathrm{m}$-thick serial sections were prepared. Immunohistochemical staining was performed by incubations of Ki-67 (Clone:Ki-S5 vat no:MS-1794-S1 1/ 100 dilution, Lab vision Corp., USA), MCM-2 (Clone: CRCT2.1 Cat no MS-1726-P1 ready to use, Lab vision Corp., USA) and EGFR (Clone:111.6 MS-178-P1 1/50 dilution, Lab vision Corp., USA) antibodies according to manufacturer's instructions using automated device. Another set of sections was stained with hematoxyline and eosin. Tonsil was used as a positive control for Ki-67 and MCM-2, cervical squamous cell carcinoma was used as a positive control for EGFR. Control slides were incubated with antibody diluent instead of primary antibody as a negative control.

The specimens were examined at $40 \times$ magnification under light microscopy by an experienced pathologist who was blind to the origin of the specimens. For each of the specimen, intensity and extent of Ki-67, MCM-2 and EGFR expression were evaluated by a scoring formula. Extent of staining was scored as $0=$ no nuclear staining, $1=<1 \%$ nuclei staining, $2=1-10 \%$ nuclei staining, $3=11-33 \%$ nuclei staining, $4=34-66 \%$ nuclei staining, $5=67-100 \%$ nuclei staining. Intensity of staining was scored as $0=$ no staining, $1=$ weak staining, $2=$ moderate staining, $3=$ strong staining. A total score was obtained by the combination of the two scores which gives a minimum score of 0 and a maximum score of 8 .

Hematoxyline and eosin stained sections were assessed for the density of inflammatory cell infiltration in the connective tissue which graded as none, mild, moderate and intense.

Mann-Whitney U test was used to compare the data between the two groups. Kruskal-Wallis test was used to compare data within each group. Any possible correlation between the variables was analyzed by Spearman's correlation. The level of significance was set at $\mathrm{P}<0.05$. All statistical analyses were conducted on computer using Statistical Package for Social Sciences (SPSS) version 20 (IBM Corp., USA).

\section{RESULTS}

The mean age of the participants in the canine group was $26.4(\min 18, \max 40)$ and the mean age of the participants in the third molar group was 26.2 (min 20, max 41). While the canine group comprised of 15 men and 25 women, the third molar group had 11 men and 19 women. 
In the canine group 5 samples had neither epithelial lining nor epithelial remnants therefore 75 specimens were included. In total, 35 specimens had both epithelial lining and epithelial remnants while 13 specimens had epithelial lining only and 27 had epithelial remnants only (Table I). Therefore epithelial linings were examined in 20 specimens in the canine group and 28 specimens in the third molar group while epithelial remnants were examined in 29 specimens in the canine group and 33 in the third molar group. In each group, the lining epithelium was stratified squamous in nature, except one sample in each group which had reduced enamel epithelium.

Representative sections stained with each marker were displayed in Figures 1, 2, and 3. Table II shows the scores of each marker evaluated for the epithelial lining of dental follicles. While the highest scores were obtained for EGFR, the lowest scores were obtained for MCM-2. The expression of each marker was similar in the epithelial lining of specimens in the third molar group and in the canine group.
The expression of Ki-67 and MCM- 2 in the epithelial remnants could be found neither in the canine group nor in the third molar group. However, EGFR expression was detected in the epithelial remnants in both groups (Fig. 4). There was no statistically significant difference in EGFR scores between the epithelial remnants in the canine group and those in the third molar group (Table III).

Table IV shows the frequency of inflammation scores determined for the connective tissue component of the dental follicles. The mean scores of inflammation were not significantly different between the two groups.

No correlation between the expressions of Ki-67, MCM-2 and EGFR was found in the 48 lining epithelium (20 in the canine group and 28 in the third molar group) of dental follicles. In addition, the age of the participants was not correlated with the expression of these markers. Ki-67 (but not the other markers studied) was positively correlated with inflammation level $(\mathrm{p}=0.005)$.

Table I. Frequency of the presence of lining epithelium and epithelial remnants in the dental follicles.

\begin{tabular}{lccc}
\hline & $\begin{array}{c}\text { Epithelial } \\
\text { lining only }\end{array}$ & $\begin{array}{c}\text { Epithelial } \\
\text { remnants only }\end{array}$ & $\begin{array}{c}\text { Epithelial lining and } \\
\text { epithelial remnants }\end{array}$ \\
\hline Canine & 6 & 15 & 14 \\
Third & 7 & 12 & 21 \\
Total & 13 & 27 & 35 \\
\hline
\end{tabular}

Table II. The mean scores of Ki-67, MCM-2 and EGFR expressions in the lining epithelium of dental follicles.

\begin{tabular}{lcc}
\hline Marker & Group & Score $($ Mean \pm SD) \\
\hline Ki-67 & Canine & $4.65( \pm 0.28)$ \\
& Third molar & $4.46( \pm 0.26)$ \\
MCM-2 & Canine & $1.25( \pm 0.33)$ \\
& Third molar & $1.39( \pm 0.33)$ \\
EGFR & Canine & $7.30( \pm 0.23)$ \\
& Third molar & $7.21( \pm 0.20)$ \\
\hline
\end{tabular}

Table III. The mean scores of EGFR expressions in the epithelial remnants within the connective tissue compartment of dental follicles.

\begin{tabular}{lcc}
\hline Marker & Group & Score (Mean \pm SD) \\
\hline EGFR & Canine & $7.28( \pm 0.14)$ \\
& Third molar & $7.21( \pm 0.16)$ \\
\hline
\end{tabular}

Table IV. The frequency of inflammation scores in the dental follicles.

\begin{tabular}{lcccc}
\hline & None & Mild & Moderate & Severe \\
\hline Canine & 30 & 7 & 1 & 2 \\
Third molar & 22 & 10 & 8 & 0 \\
\hline
\end{tabular}




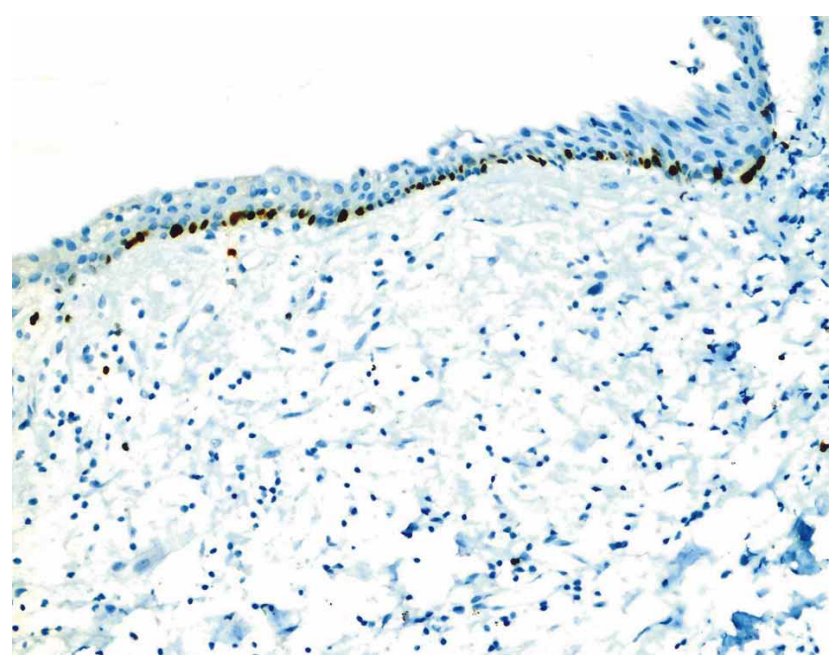

Fig. 1. The expression of Ki-67 in the lining epithelium (X40).

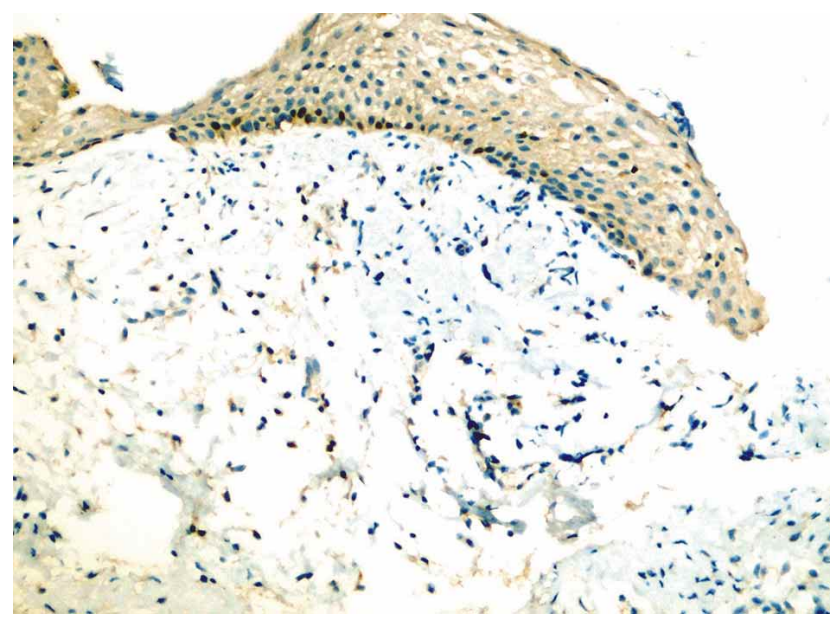

Fig. 2. The expression of MCM-2 in the lining epithelium (X40).

\section{DISCUSSION}

While there is a consensus on the removal of impacted teeth that are associated with pathology, prophylactic extraction of asymptomatic impacted teeth have been controversial. Some researches suggested that all impacted teeth should be removed to eliminate the chance of any pathology development (Rakprasitkul, 2001; Saravana \& Subhashraj, 2008; Brkic et al., 2010), others claimed that prophylactic removal is unnecessary as the potential of any pathology development is very slim (Saraçoglu et al.; Stephens et al., 1999; Stathopoulos et al., 2011). Despite this disagreement, only a few studies investigated cellular activity of the dental follicles of asymptomatic impacted third molars in comparison with that of odontogenic pathologies

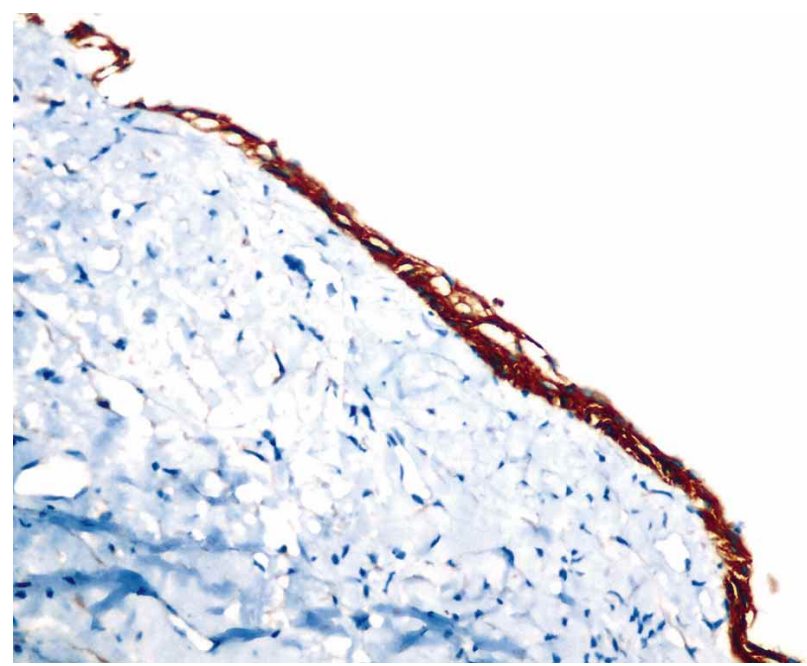

Fig. 3. The expression of EGFR in the lining epithelium (X40).

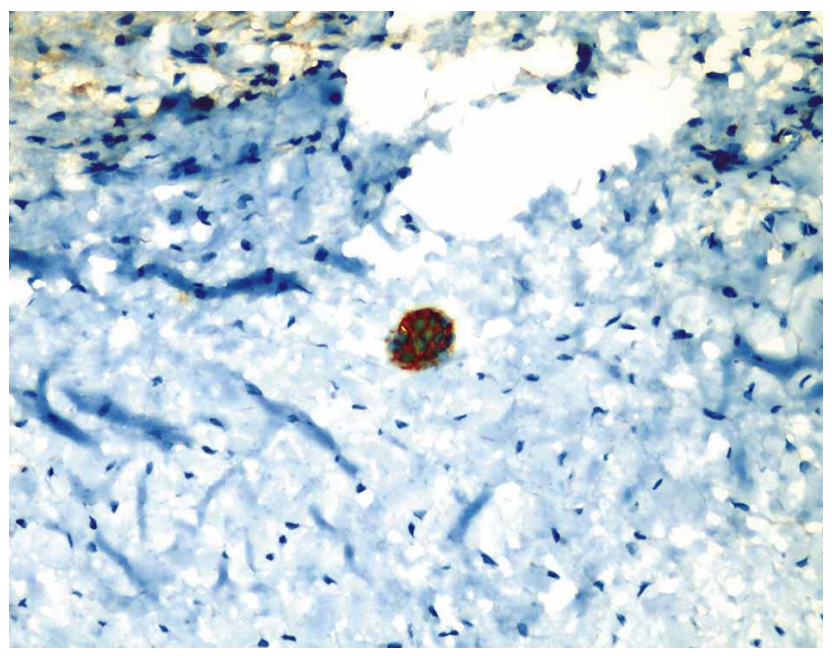

Fig. 4. The expression of EGFR in the remnants of odontogenic epithelium (X100).

(Saraçoglu et al.; Edamatsu et al.; Cabbar et al.; Güler et al.).

In the present study, out of 75 specimens 48 had epithelium covering the connective tissue component. Of the 48 specimens with epithelium lining, only one specimen in each group had reduced enamel epithelium, the rest were composed of stratified squamous epithelium. Some authors considered any dental follicle with squamous epithelium spreading along its surface as pathologic and the first visible sign of cystic transformation of the dental follicle (Oliveira et al., 2011; Cabbar et al.; Güler et al.; Godoy et al., 2007). According to Kim \& Ellis (1993), evaluation of 
the dental follicles based solely on histological findings may lead to incorrect interpretation and the clinical, radiographic, and microscopic features should be considered in concert in arriving at a final diagnosis. In compliance, presence of stratified squamous epithelial lining was deemed as a modification of dental follicle rather than suggestive of a dentigerous cyst. This was on the basis that pericoronal radiolucency of $2.5 \mathrm{~mm}$ or less in width (the inclusion criteria of our study) was regarded non-pathologic.

In our opinion, from the findings of the present study (that the presence of stratified squamous epithelium) one cannot deduce that removal of an impacted tooth to prevent the possibility of pathology transformation of odontogenic epithelium is justified. Nonetheless, the squamous metaplasia of the epithelial lining indicates the differentiation potential of dental follicles (Oliveira et al., 2012). A higher expression of integrins which are involved in epithelial cell differentiation was found in dentigerous cyst and dental follicles with squamous lining compared to those with single layer lining epithelium (Godoy et al.). In addition, it can be at least assumed that there is a certain level of metabolic activity present within the lining odontogenic epithelium as all the proliferative markers investigated were expressed in the lining epithelium of the dental follicles. We were unable to statistically compare the metabolic activity of the single strand reduced enamel epithelium and the stratified variant as we had only two specimens with reduced enamel epithelium. Adelsperger $e t$ al., found that 5 of 8 specimens with squamous metaplasia demonstrated PCNA uptake, whereas none of 10 specimens with no squamous metaplasia were PCNA positive while de Oliveira et al. (2011) demonstrated positivity for proliferating cell nuclear antigen (PCNA) in 3 out of 15 dental follicles with stratified squamous lining epithelium. The authors concluded that cellular proliferative activity might be active in dental follicles showing squamous metaplasia.

It seems that the squamous lining epithelium of the dental follicle has a higher turn-over compared to oral mucosa and a lower turn-over compared to some odontogenic pathologies. Cabbar et al., showed that the expressions of both Ki-67 and MCM-2 were higher in the squamous epithelium of dental follicles of radiographically asymptomatic lower impacted third molars (a mean labeling index of $12.3 \%$ and $6.9 \%$, respectively) compared to healthy gingiva (a mean labeling index of $6.2 \%$ and $4.5 \%$, respectively). The same research group (Güler et al.) reported that Ki-67 and MCM-2 expressions in dental follicle with squamous epithelium (a mean labeling index of $11.3 \%$ and $7.5 \%$, respectively) were lower than those in radicular cyst (a mean labeling index of $12.2 \%$ and $19.2 \%$, respectively) and keratocystic odontogenic tumor (a mean labeling index of $16.2 \%$ and $15.4 \%$, respectively). However, interestingly Ki-67 and MCM-2 expressions were found similar in dental follicle and dentigerous cyst (Edamatsu et al.; Güler et al.). On the other hand, Saracoglu et al., found that while the highest number of MIB-1 positive cells was seen in the keratocysts, similar numbers of MIB-1 positive cells within the epithelium of oral mucosa, and of radicular and dentigerous cysts were observed.

Cabbar et al., found that the mean Ki-67 and MCM-2 expressions were $10.7 \%$ and $6.1 \%$, respectively in the remnants of odontogenic epithelium within the connective tissue of dental follicle which were similar to those detected in the lining squamous epithelium. In contrast, Saracoglu et al., reported that whereas epithelial lining of oral mucosa and various odontogenic cysts showed positivity for MIB-1 (an antibody used for the expression of Ki-67), no MIB-1 positive cells in the odontogenic epithelial remnants were detected. In the present study, epithelial remnants within the connective tissue component of all 62 specimens were negative for the expression of Ki-67 and MCM-2. Although Ki-67 and MCM2 expressions were positive in the lining epithelium and negative in the epithelial remnants, similar levels of EGFR expression were detected both in the epithelial remnants and in the lining epithelium. Ki-67 is one of the most commonly used marker to determine the growth fraction of a given cell population and is present during all active phases of the cell cycle but is absent from resting cells (Macluskey et al.). MCM2, a part of MCM 2-7 complex, is an important factor in forming of the replication fork and in regulation of DNA synthesis. Similarly high levels of MCM proteins are expressed in proliferating cells but they are not detected in resting phase of the cell cycle, differentiated or senescent cells (Szelachowska et al.; Kearsey \& Labib, 1998). On the other hand, EGF has a role to trigger cell proliferative activity allowing proliferation signals to be received, transduced, and transmitted to the nucleus in response to a stimulus (Jorissen et al., 2003). Our finding may then indicate that unlike epithelial lining, epithelial remnants do not actively proliferate but they have similar level of proliferative potential when stimulated. In another study, compared to that in non-smokers, the expression of EGFR in the pericoronal follicles of asymptomatic mandibular third molars in smokers was higher. It was claimed that increased expression was due to the increased pathologic potential of pericoronal tissues in smokers (Özarslan et al.).

It was proposed that rather than staining intensity, the distribution of growth factor receptors (membrane only, cytoplasm only, or combined membrane and cytoplasmic) was more relevant to indicate different degrees of cell responsiveness to proliferation stimulus. While cells presenting a membrane only staining may respond quicker to stimulus, receptors partly or totally internalized into cytoplasm tend to show slower, physiological cell turnover (da Silva Baumgart 
et al.). The same authors, reported that while epithelial cells of healthy oral mucosa showed combined membrane and cytoplasmic staining, epithelial cells of carcinoma specimens showed membrane-only staining. The authors also reported that all reduced enamel epithelium and majority of epithelial remnants in dental follicle specimens presented either a cytoplasm-only or a combined staining pattern. Furthermore, when compared with the oral mucosa, the frequency of cytoplasm-only staining was significantly higher in the epithelial remnants. Based on these findings these authors suggested that in spite of the presence of EGFR in the epithelial remnants, the proliferative capacity is reduced in these cells. The chief objective of the present study was to compare the proliferative activity of dental follicles of the impacted maxillary canines to that of the impacted mandibular third molars in an attempt to contribute an answer to the question why higher rate of pathology development is associated with mandibular third molars than the rest of the dentition. We found that expression of all proliferation-related markers investigated (Ki-67, MCM-2 and EGFR) both in the epithelial remnants within the connective tissue and in the epithelial lining of the dental follicle of impacted mandibular third molar was not statistically different than that of the impacted maxillary canine. No difference in cell proliferative activity between the two groups may point out that both impacted canine and third molar carry similar potential to be the source of pathology. The reason for higher ratio of pathology associated with mandibular third molars may be most probably due to their higher incidence of impaction. Therefore impaction of teeth itself poses as a potential risk factor to pathology development. However, other risk factors may also contribute to the increased proliferation potential of embryogenic odontogenic structures.

While the age of the patients does not seem to be associated with the expression of proliferation markers, level of inflammation within the connective tissue component of the dental follicle may contribute to the risk of pathology development in the dental follicle as we observed that expression of Ki-67 on the lining epithelium (but not the other markers studied) was positively correlated with inflammation level. This finding is consistent with previous studies. Increased rates of MIB-1 positivity (Saraçoglu et al.), Ki-67 positivity (Edamatsu et al.; Cabbar et al.; Güler et al.) and MCM-2 positivity (Cabbar et al.; Güler et al.) were demonstrated in dental follicles with more inflammatory changes than those with less inflammatory changes. Higher expression of proliferative markers in inflamed tissues was explained by the proposition that inflammation in the connective tissue component of dental follicles may regulate the cell turnover of epithelial components and may stimulate their proliferative activity (Edamatsu et al.).

In conclusion, the proliferative capacity of dental follicles surrounding the crown of impacted asymptomatic mandibular third molars and maxillary canine is similar both in the lining epithelium and in the epithelial remnants. Based on this finding, similar pathologic potential of impacted maxillary canine and mandibular third molars should be taken into account for decision making of the treatment approach of these teeth.

Proliferation-related markers which may indicate active proliferative activity were detected in the lining epithelium of the follicles of mandibular third molars and maxillary canine. In addition, follicles of both mandibular third molars and maxillary showed expression of EGFR in the epithelial remnants indicating that these cell clusters have a potential to grow when activated. As proliferative activity of cells (actively or potentially) carries the potential of developing pathology, these findings may advocate the opinion that prophylactic extraction of both impacted third molars and canines may be considered. When not opted for extraction, periodic followup is needed for any changes.

FUNDING. This study was funded by: University Scientific Research Fund.

KÖMERIK, N.; TUFAN, A. \& KAPUCUOGLU, N. Comparación de la actividad proliferativa de las células epiteliales entre los folículos de dientes impactados. Int. J. Morphol., 32(4):1296-1302, 2014.

RESUMEN: El objetivo fue comparar la actividad proliferativa de los folículos dentarios que rodean a dientes caninos maxilares y terceros molares mandibulares impactados. Luego de realizada la extracción dentaria, se removieron 40 folículos dentarios de los terceros molares mandibulares impactados y 40 de caninos maxilares impactados. Se evaluó la actividad proliferativa de las células epiteliales de estas muestras mediante marcaje inmunohistoquímico para Ki-67, para la proteína de mantenimiento minicromosoma 2 (MCM-2) y para el receptor del factor de crecimiento epitelial (EGFR). Se evaluó la intensidad y extensión de Ki-67, MCM-2 y las expresiones de EGFR mediante una fórmula de puntuación. El epitelio de revestimiento de los folículos correspondientes a los caninos maxilares presentaron valores promedios de 4,65 $\pm 0,27$ para Ki- $67,1,25 \pm 0,33$ para MCM2 y 7,30 $\pm 0,23$ para EGFR, que no fueron significativamente diferentes de los expresados en los folículos de terceros molares mandibulares $(4,46 \pm 0,26$ para Ki-67, 1,39 $\pm 0,33$ para MCM-2 y 7,21 $\pm 0,20$ para EGFR). La expresión de Ki-67 y MCM-2 no pudo ser detectada en los restos epiteliales dentro del tejido conectivo en ambos grupos. La expresión de EGFR, detectada en los restos epiteliales en ambos grupos, no fue significativamente diferente (7,28 $\pm 0,14$ en el grupo de los caninos, y 7,21 $\pm 0,16$ en el grupo de los terceros molares). Sobre la base de estos resultados, se puede deducir que la retención de terceros molares y caninos maxilares conlleva un riesgo similar para el desarrollo de patología.

PALABRAS CLAVE: Folículo dentario; Ki-67; MCM-2; EGFR; Inmunohistoquímica. 


\section{REFERENCES}

Adelsperger, J.; Campbell, J. H.; Coates, D. B.; Summerlin, D. J. \& Tomich, C. Early soft tissue pathosis associated with impacted third molars without pericoronal radiolucency. Oral Surg. Oral Med. Oral Pathol. Oral Radiol. Endod., 89(4):402-6, 2000.

Brkic, A.; Mutlu, S.; Koçak-Berberoglu, H. \& Olgaç, V. Pathological changes and immunoexpression of p63 gene in dental follicles of asymptomatic impacted lower third molars: an immunohistochemical study. J. Craniofac. Surg., 21(3):854-7, 2010.

Cabbar, F.; Güler, N.; Comunog ${ }^{` l u, ~ N . ; ~ S e n c ̧ i f t, ~ K . ~ \& ~ C o ̈ l o g ~}{ }^{` l u}$, S. Determination of potential cellular proliferation in the odontogenic epithelia of the dental follicle of the asymptomatic impacted third molars. J. Oral Maxillofac. Surg., 66(10):2004-11, 2008.

Chu, F. C.; Li, T. K.; Lui, V. K.; Newsome, P. R.; Chow, R. L. \& Cheung, L. K. Prevalence of impacted teeth and associated pathologies--a radiographic study of the Hong Kong Chinese population. Hong Kong Med. J., 9(3):158-63, 2003.

da Silva Baumgart, C.; da Silva Lauxen, I.; Filho, M. S. \& de Quadros, O. F. Epidermal growth factor receptor distribution in pericoronal follicles: relationship with the origin of odontogenic cysts and tumors. Oral Surg. Oral Med. Oral Pathol. Oral Radiol. Endod., 103(2):240-5, 2007.

Edamatsu, M.; Kumamoto, H.; Ooya, K. \& Echigo, S. Apoptosis-related factors in the epithelial components of dental follicles and dentigerous cysts associated with impacted third molars of the mandible. Oral Surg. Oral Med. Oral Pathol. Oral Radiol. Endod., 99(1):17-23, 2005.

Godoy, G. P.; da Silveira, E. J.; Lins, R. D.; de Souza, L. B.; de Almeida Freitas, R. \& Queiroz, L. M. Immunohistochemical profile of integrins in enlarged dental follicles and dentigerous cysts. Oral Surg. Oral Med. Oral Pathol. Oral Radiol. Endod., 104(6):e29-34, 2007.

Güler, N.; Comunoglu, N. \& Cabbar, F. Ki-67 and MCM-2 in dental follicle and odontogenic cysts: the effects of inflammation on proliferative markers. Scientific WorldJournal, 2012:946060, 2012.

Jorissen, R. N.; Walker, F.; Pouliot, N.; Garrett, T. P.; Ward, C. W. \& Burgess, A. W. Epidermal growth factor receptor: mechanisms of activation and signalling. Exp. Cell Res., 284(1):31-53, 2003.

Kearsey, S. E. \& Labib, K. MCM proteins: evolution, properties, and role in DNA replication. Biochim. Biophys. Acta, 1398(2):113-36, 1998.

Kim, J. \& Ellis, G. L. Dental follicular tissue: misinterpretation as odontogenic tumors. J. Oral Maxillofac. Surg., 51(7):762-7, 1993.

Liu, S. C. \& Klein-Szanto, A. J. Markers of proliferation in normal and leukoplakic oral epithelia. Oral Oncol., 36(2):145-51, 2000.

Macluskey, M.; Ogden, G. R.; Green, M.; Chisholm, D. M.; Schor, S. L. $\&$ Schor, A. M. The association between epithelial proliferation and disease progression in the oral mucosa. Oral Oncol., 35(4):409-14, 1999.
Ochsenius, G.; Escobar, E.; Godoy, L. \& Peñafiel, C. Odontogenic cysts: analysis of 2,944 cases in Chile. Med. Oral Patol. Oral Cir. Bucal, 12(2):E85-91, 2007.

Oliveira, D. M.; Silveira, M. M. F.; Andrade, E. S. S.; Sobral, A. P. V.; Martins-Filho, P. R. S.; Santos, T. S. \& Oliveira, P. L. A. Immunohistochemical analysis of proliferating cell nuclear antigen (PCNA) in dental follicles of impacted third molars. Int. J. Morphol., 29(2):526-31, 2011.

Oliveira, D. M.; Siveira, M. M. F.; Andrade, E. S. S.; Sobral, A. P. V.; Martins-Filho, P. R. S.; Santos, T. S.; Oliveira, P. L. A.; Peixoto, A. C.; Santos, J. A. S. S. \& Piva, M. R. Immunohistochemical analysis of human homologue of drosophila patched (PTCH) in dental follicles of impacted third molars. Int. J. Morphol., 30(1):105-9, 2012.

Özarslan, S. K.; Baykul, T.; Bas ,ak, K.; Koçer, G. \& Tüzüm, S, Detection of epidermal growth factor receptor intensity in asymptomatic fully impacted lower third molar follicles of smoking and nonsmoking patients. J. Craniofac. Surg., 24(2):435-8, 2013.

Piattelli, A.; Lezzi, G.; Fioroni, M.; Santinelli, A. \& Rubini, C. Ki-67 expression in dentigerous cysts, unicystic ameloblastomas, and ameloblastomas arising from dental cysts. J. Endod., 28(2):55-8, 2002.

Rakprasitkul, S. Pathologic changes in the pericoronal tissues of unerupted third molars. Quintessence Int., 32(8):633-8, 2001.

Saraçoglu, U.; Kurt, B.; Günhan, O. \& Güven, O. MIB-1 expression in odontogenic epithelial rests, epithelium of healthy oral mucosa and epithelium of selected odontogenic cysts. An immunohistochemical study. Int. J. Oral Maxillofac. Surg., 34(4):432-5, 2005.

Saravana, G. H. \& Subhashraj, K. Cystic changes in dental follicle associated with radiographically normal impacted mandibular third molar. Br. J. Oral Maxillofac. Surg., 46(7):552-3, 2008.

Stephens, R. G.; Kogon, S. L. \& Reid, J. A. The unerupted or impacted third molar--a critical appraisal of its pathologic potential. J. Can. Dent. Assoc., 55(3):201-7, 1989.

Stathopoulos, P.; Mezitis, M.; Kappatos, C.; Titsinides, S. \& Stylogianni, E. Cysts and tumors associated with impacted third molars: is prophylactic removal justified? J. Oral Maxillofac. Surg., 69(2):4058, 2011.

Szelachowska, J.; Dziegiel, P.; Jelen-Krzeszewska, J.; Jelen, M.; Matkowski, R.; Pomiecko, A.; Spytkowska, B.; Jagas, M.; Gisterek, I. \& Kornafel, J. Mcm-2 protein expression predicts prognosis better than Ki-67 antigen in oral cavity squamocellular carcinoma. Anticancer Res., 26(3B):2473-8, 2006.

Correspondence to:

Nurgul Komerik

Suleyman Demirel Universitesi

Dis Hekimligi Fakultesi

Isparta

TURKEY

Received: 24-01-2014

Accepted: 23-09-2014

\section{Email: nurgulkomerik@gmail.com}

